\title{
Anton Çehov’un Martı Oyununda Yapısalcı Yöntem Açısından Bir Gösterge Olarak "Tekrarlar"
}

\section{Elif TÜFEKÇї}

\section{Özet}

Yapısalcı yöntemin temel hedeflerinden birinin şifrelenmiş bir dizge olarak kabul edilen bir metni çözümlemek olduğu kabul edilir. Bu çözümleme sırasında metinde somut olarak var olan açık göstergeler değil, işaret ettiği anlam kolayca belirlenemeyen örtük göstergeler önem taşır. Bir başka kabul gören konu ise başarılı bir yapıtın örtük göstergelerle şifrelenmiş olduğu üzerinedir. Oyun yazarlığının ve modern öykünün en önemli temsilcilerinden olan Anton Çehov'un Martı (Cayka; 1896) adll oyunu yukarıda sözü edilen şifrelenmiş dizgeye verilebilecek en iyi örneklerden biridir. Bu bağlamda, makale yapısalcılı̆̆ın metnin derin yapısına ulaşma ereği ışığında Martı oyunundaki temel kurgulamanın ve oyun kişisi yönelimlerinin metodolojik olarak saptanmasını hedeflemiştir. Bu hedef doğrultusunda oyun eşzamanlı bir yöntemle ele alınmış, tekrarlar bă̆lamında örtük göstergelerin açık göstergelere çevrilmesi ile oyunun üzerine oturduğu tekrarların yapısı görüntülenmiştir.

\begin{abstract}
It is accepted that one of the major aims of structural method is to analyze a text that is considered as an encoded system. During that analysis not the concrete indicators that openly exist in the text but also the covered meanings that they address cannot be easily identified gains importance. Another point that is generally accepted is the successful works are encoded by using that kind of covered indicators. Seagull (Cayka; 1896) of Anton Chekhov, that is one of the most important representatives of play and modern short story writers, is one of the best examples that can be given about the above expressed encoded system. In this context, this article aims to identify the basic fiction editing and approaching to play characters of Seagull methodologically by taking the main goal of structuralism that is trying to reach the deep structure of the encoded text as a base. Parallel to this aim, the play is handled in a concurrent method and the turning of the covered indicators in repeated dialogs to open indicators and the structure of these repeats on which the play is built is observed.
\end{abstract}

Yüzeydeki görüntünün altında, derinde yatan kuralların ve yasaların oluşturduğu yapıyı arayan bir yöntem olan yapısalcı yöntem, yapıyı oluşturan birimlerin tek başlarına anlam taşımadıklarını, yapı içinde birbirleriyle olan bağıntılardan anlam kazandıklarını savunur. Ele alınan nesnenin "kendi başına ve kendi kendisi için" incelenmesi; nesnenin kendi öğeleri arasındaki bağıntılardan oluşan bir "dizge" olarak ele alınması; söz konusu dizge içinde her zaman işlevi göz önünde bulundurma ve her olguyu bağlı olduğu dizgeye dayandırma zorunluluğunun sonucu olarak, nesnenin artsüremlilik içinde değil, eşsüremlilik içinde ele alınması; bunun sonucu olarak, köken, gelişim, etkileşim vb. gibi artsüremsel sorunlara ancak nesnenin elden geldiğince eksiksiz bir çözümlemesi yapıldıktan sonra ve bunların da eşsüremsel olgular gibi dizgesel olarak ele alınmalarını sağlayacak yöntemler geliştirildiği ölçüde yer verilmesi yapısalcı yöntemin temel ilkeleri olarak belirir.

Yapısalcığın temel kaynaklarından birini oluşturan Saussure'ün dili incelemek için herhangi bir dış gerçekliğe başvurmaması, sistemin bir başka ifadeyle dizgenin, gerçeklikten bağımsı, kendi

\footnotetext{
* Araştırma Görevlisi, Ankara Üniversitesi, Dil ve Tarih-Coğrafya Fakültesi, Tiyatro Bölümü
} 
başına işleyen bir bütün olması bağlamındaki görüşleri ve bu görüşlerin izinden giden Todorov, Barthes ve Greimas gibi yapısalcıların da aynı biçimde yazarla, tarihle ya da metin dışı dünya ile yapıt arasında bağ kurmak gereğinden uzak yaklaşımları yöntemi tanımlar: Martı adlı oyunda tekrarların yapısalcı yöntem açısından bir gösterge olarak incelemesinde artzamanlı değil eşzamanlı bir yaklaşım benimsenmiştir.

Göstergeyi oluşturan gösteren ve gösterilen kavramlarını kağıdın iki yüzüne benzeten Saussure, gösteren ile gösterilenin biçim ve içerik olarak birbirlerinden ayrılamayacağını söyler.1 Buradan hareketle yapısalcı yöntemin temel hedeflerinden biri olan örtük göstergeleri çözümleme hedefi makalenin çıkış noktasını oluşturacaktır. Anton Çehov'un Martı adlı oyununda tekrarlar bağlamında somut gösterenlerden yola çıkılıp, örtük göstergeler açık göstergeye dönüştürülecek ve söz konusu göstergelerin dizge içindeki yeri belirlenecektir.

Anton Çehov'un Martı (Çayka; 1896) adlı oyunu, modern / gerçekçi tiyatronun köşe taşlarından biri olarak kabul edilir. Oyunun yüzey yapısına bakılarak olaylar dizisi şu biçimde özetlenebilir: Treplev, yaşayacak başka bir yeri olmadığından dayısı Sorin'in çiftliğinde yaşamakta, dönemin edebiyat anlayışına göre "yenilikçi" olarak tanımlanabilecek yazarlık denemeleri yapmaktadır. Yazdığı "yenilikçi” oyunu sahnelemesi, dönemin kabul gören tiyatro anlayışının temsilcisi olan annesi Arkadina ve onun popüler yazar sevgilisi Trigorin'in çiftliği ziyaret ettikleri bir yaz tatiline rastlar. Oyunun tek oyuncusu yakın çiftliklerden birinde yaşayan, aktris olmak isteyen ve Treplev'in aşkla bağlı olduğu Nina'dır. Oyunun sahnelenişi sırasında annesinin tiyatro anlayışı ile ilgili küçümseyici tavırlarına öfkelenen Treplev, oyunu yarıda keser. Aynı akşam Nina ile Trigorin arasında başlayan aşk Arkadina'yı da Treplev'i de rahatsız edecek, Treplev'in Trigorin'i düelloya davet etmesini engelleyen Arkadina, oğlunun başarıya ulaşmayan intihar girişiminden sonra Trigorin ile birlikte şehre dönecektir. Ancak Nina aktris olmak için evden kaçacak ve şehirde Trigorin ile buluşmak üzere sözleşecektir. Dördüncü perde oyunun ilk üç perdesinden iki yıl sonra başlar. Sorin çiftliğinin kahyası Şamrayev'in Treplev'e umutsuzca aşık olan kızı Maşa, öğretmen Medvedenko ile evlenmiş ve bir bebeği olmuştur. Treplev'in yazdıkları edebiyat dergilerinde yer bulmakla beraber edebiyat çevrelerinde büyük yankılar uyandırmamıştır. Nina, şehre gittiğinde Trigorin ile bir ilişki yaşamış, ondan bir bebek sahibi olmuş, bebeğini kaybetmiş ve Trigorin tarafından terk edilmiştir. Arkadina, kendisine geri dönen Trigorin ile birlikte ağabeyi Sorin'in rahatsızlı̆̆ 1 nedeniyle çiftliğe döner. Aynı günlerde yörede olduğu bilinen Nina gizlice Treplev'le görüşür. Görüşmelerinden Nina'nın ancak ikinci sınıf bir oyuncu olabildiği, Trigorin'i hala sevdiği ve ruhsal dengesini kaybettiği

1 Ferdinand de Saussure. Genel Dilbilim Dersleri. Çev.: Berke Vardar. (İstanbul: Multilingual Yayınları, 1998), s. 108. 
anlaşılır. Nina'nın ardından yazdıklarını yırtıp atan Treplev'in kendini vurduğu, aile dostu doktor Dorn'un ağzından duyulur.

Oyunun birinci perdesi akşam saatlerinde başlar. İkinci perde öğlen, üçüncü perde sabah ve dördüncü perde tekrar akşam saatlerinde geçer. Buradan hareketle oyunun zaman düzleminde bir tersine işleyişi olduğu görülür: Oyunun zaman düzleminde tersine işlemesi, akşam başlayan oyunun iki yıllık bir aradan sonra geriye giderek akşam saatinde sonlanması zamanın ilerlediğini değil, geriye gittiğini imler; tekrar eden bir döngüye işaret eder. Öyle ki, oyunun dördüncü perdesi, birinci perdesinin tekrarı niteliği taşır. Birinci perdede şehirden çiftliğe gelenlere sahnelenen tiyatro oyunu dördüncü perdede yine şehirden çiftliğe gelenler için oynanan tombala oyunu ile katlanır. Benzer bir tekrar, uzam düzleminde de saptanır: Oyun açık alanda başlar, ikinci perde açık alanda devam eder, üç ve dördüncü perde giderek daralan kapalı alanlarda geçer: Zaman düzleminde, zamanın tersine işleyişi ile anlatılan geriye gidiş, uzam düzlemine çıkışsızlığı imleyen bir umutsuzluğa gidiş olarak yansır. Yazar, geriye işleyen zaman ve giderek daralan uzamla oyun kişilerini tekrar ederek devam eden ve edecek olduğu açık olan bir döngüye sokar. Giderek daralan / sıkışan uzam ve tekrarlayarak geriye / olumsuza giden zaman içinde oyun, yaşlı ve genç kuşağı başladıkları noktadan daha umutsuz, daha mutsuz, daha geleceksiz bir noktaya vardırır: Oyunun başında Nina’ya aşık olan Treplev, dördüncü perdeye gelindiğinde artık arada Trigorin olmasa da Nina'yla birlikte olmayacağını anlar. Ünlü bir aktris olmak üzere evden kaçan Nina’nın “ikinci sınıf” bir aktris olmaktan öteye gidemeyeceği açıktır. Maşa, Treplev'e olan aşkına asla karşılık bulamayacak ve Medvedenko'yla asla mutlu olamayacaktır. Medvedenko, oyunun başında Maşa'ya olan aşkını anlatmak için yürüdüğü yolu, oyunun sonunda bu kez onu evine döndürebilmek adına hala yürüyor olacaktır. Söz konusu oyun kişilerine görece yaşlı olan kuşağın, şehirde yaşamayan temsilcileri olan Şamrayev, Polina ve Dorn'a bakıldığında, bu kişilerin bugünü geçmişin tekrarı gibi algıladıkları görülür. Şehirliliği temsil eden Sorin, Trigorin ve Arkadina ise ancak kendilerini aldatacak kadar umut taşırlar.

Çehov'un Martı'yı, oyun kişilerinin gündelik yaşamları içerisindeki diyaloglarıyla biçimlendirdiği görülür. Ancak söz konusu diyaloglar, eylem üretmeyen tekrarlar olarak oyunu oluşturur. Oyun kişilerinin tepkileri eyleme dönüşmez sadece tekrarlanan sözler olarak kalır. Çehov, eylemsizliğin tekrarından anlam üretmiştir:

(...) Kısa süreli bir öfke, bir sitem, bir şikayet nöbeti olaylarda bir gelişim yaratmaz, fakat hem tepkiyi gösteren kişinin, hem tepkisiz kalan öteki kişilerin iç dünyalarında kopan firtınayı duyurmayı başarır. Kişilerin duygu ve düşünce burgaçlarını ele veren, kırık dökük sözler, yarım kalmış davranışlardır.(...) Martı'da Treplev'in intihar etmeye kalkışıp bunu becerememesi, üstelik annesine karşı bir protesto anlamı taşıyan böyle bir 
davranıştan sonra başındaki yarayı gene annesine sardırması, eylemsizlikten anlam üretmeye bir örnektir.1

Çehov, söz konusu anlamı üretirken oyun kişilerinin eylemlerini ateşleyen temel dürtüyü, var oldukları yerden uzaklaşma isteği olarak belirler. Martı'da oyun kişileri yaşadıkları yerden uzaklaşmak, büyük kentlere gitmek isterler. Aynı zamanda, içinde bulundukları zaman diliminin de öncesinde ya da sonrasında yaşamak dileğindedirler. Hem zaman, hem uzam daralmışlı̆̆ı, oyun kişilerini bir tekrar çemberine sokar. Uzaklaşma isteği bir ateşleyici güç oluştururken, oyun kişileri hem yaşadıkları çembere bağlıdırlar hem de bu çemberi kıracak güçleri olmasını özlerler. Buradan hareketle, oyunun temel tekrar ekseni "gitmek ve gelmek" olarak belirir. Her perdede şehirde yaşayan oyun kişilerinin çiftliğe gelip gidişlerinin ana tekrar eksenini belirlediği oyunda, söz konusu tekrar ulamı aynı zamanda dramatik yapının ateşleyici unsurunu oluşturur. Söz konusu ateşleyici unsur ile birlikte oyun, oyun kişilerinin yönelimlerinde alt tekrar eksenleri oluşturacak biçimde gelişir. Başka bir ifadeyle oyunun temel izleğinde "gitmek ve gelmek" temel tekrar olarak diş daireyi oluştururken, oyun kişileri diğer tekrarlarla iç daireleri çizer.

Oyunun birinci perdesinde Arkadina ve Trigorin'in şehirden çiftliğe gelmesi diğer oyun kişileri için oyun boyunca ateşleyici unsur olurken, beraberinde alt tekrar eksenleri getirir: Söz konusu oyun kişilerinin gelişiyle "Geçmiş”, "Gelecek”, "Mutsuzluk”, "Mutluluk”, “Aşk”", "Sınıf”, "Sanat ile İlgi”, "Başarı", "Kent”, "Köy”, "Gizlilik / Yakalanma”, “Av / Avcı”, "Kendini Başkalarından Aktarmak", "Kendini Kendi Gözleriyle Yargılamak", "Yaş", "Birilerinin Birilerini Anlatması", "Sağlık”, "Para”, “Aile”, “Tiyatro”, “Eser Adları”, "Yazar Adları”, "Sayı”, “Zaman”, "Şarkı/ Müzik”, "Yürümek”, “Alıntı", “Göl”, “Martı”, "Hava Durumu / Fırtına”, “Kıskançlık”, “Saçma”, “Şöhret”, "Benzetmeler" ve "Renk" başlıkları altında toplanan alt tekrar eksenleri oluşur.

Oyunun her perdesinde "Arkadina ve Trigorin'in çiftliğe gelmesi ve gitmesi” temel tekrar ekseninin yarattığı ateşleyici güç ile, oyun kişileri oyun boyunca, her perdede tekrar eden alt tekrar eksenleriyle yönelimlerini belirler. Oyun kişilerinin eylemlerini / eylemsizliklerini belirleyen alt tekrar eksenleri saptanarak oyunun üzerine oturduğu tekrarlar ortaya çıkar.

\section{PERDE}

\section{Perdede Temel Tekrar Ekseni :}

Gitmek ve Gelmek : Arkadina ve Trigorin'in yaz tatili için çiftliğe gelmeleri.

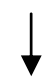

Ateşleyici Unsur

1 Sevda Şener. Yașamın Kırılma Noktasında Dram Sanatı. (İstanbul:Yapı Kredi Yayınları,1997), s. 58. 
Medyedenko: Nina-Treplev birlikteliğine özenmek.

Maşa: Treplev'e aşkını Dorn'a açıklamak.

Treplev: Yazar olma isteği.

Nina: Aktris olma isteği.

Polina: Dorn'a karşı aşkının su yüzüne çıkması.

Şamrayev: Tiyatro anılarını canlandırmak.

Sorin: Yazarlık hayallerini hatırlatmak.

\section{Perdede Temel Tekrar Ekseni :}

Gitmek ve Gelmek : Arkadina ve Trigorin'in yaz tatili için çiftliğe gelmeleri.

Oyunun her perdesinde gelip gidişleriyle bir temel tekrar ekseni oluşturan Arkadina ve Trigorin, oyunun şehirliliği temsil eden oyun kişileridir. Oyunun görece yaşlı oyun kişilerinin kırsal kesiminde yaşayanları, nasıl geçmişi bugünde yaşatmak istiyorlarsa, şehirde yaşayan Arkadina ve Trigorin ise var oluşlarını "şimdi" ye denklerler. Arkadina, oyun boyunca şimdide var olan statüsünü kaybetmemek adına savaşır: Gerçekte kırk iki yaşında olmasına rağmen Treplev yanında yokken otuz altı yaşında olduğunu söylemesi, Treplev'in yenilikçi yaklaşımını hoyratça aşağılaması, yanında başka aktrislerden söz edilmesinden duyduğu rahatsızlık, Trigorin'i kaybetme tehlikesi karşısında takındığı tutum varolan statüsünü kaybetmemek adınadır. Bu göstergenin göstereni Treplev'in oyunun birinci perdesinde annesinin boş inançlarına vurgu yapmasıdır: "Sonra, boş inançları vardır; yan yana ü̧̈ mum yakılmasından, on ü̧̈ saylsından korkar.” 1 Treplev'in oyunun başında vurgu yaptığ1 “uğursuzluk” inancı, Arkadina'nın bugün elinde olanları kaybetme korkusu ile örtüşür. Şimdide var olma çabasının bir diğer örneği Trigorin'dir. Gençliğini editör kapılarında heba etmesinin sonucunda hatırı sayılır bir üne kavuşmuş olmasına rağmen huzursuzdur. Çünkü ünü yalnızca bugünle sınırlı kalacak gelecek kuşaklar onu yazdıklarıyla değil, asla Tolstoy ya da Turgenyev gibi yazamayışıyla anımsayacaklardır. Bu huzursuzluk onu sürekli yazmaya, yeni yapıtlar için notlar almaya ve hatta gündemde kalmak adına Arkadina ile birlikteliğe zorlar. Bütün bunlardan sıyrılıp, sakin bir göl kıyısında balık tutmayı özlediğini dile getirse de şimdide var olmak için yazmak ve bu yaşantıyı devam ettirmek zorundadır. Bu göstergenin göstereni yine Treplev'in ağzından duyulacaktır: Sonra Trigorin, pek doğal olarak, onu bırakıp eski ilişkilerine döndü. Zaten bu ilişkileri hiçbir zaman koparmamıştı, kurnazlıkla hepsini birden idare edecek karakterde biridir çünkü.,"

Her perdede şehirde yaşayan Arkadina ve Trigorin'in çiftliğe gelip gidişleri ana tekrar eksenini belirler. Söz konusu ana tekrar ekseninin ateşleyici gücü ile yönelimleri beliren oyun kişileri alt tekrar eksenleriyle oyunda var olurlar. Birinci perdede Arkadina ve Trigorin'in yaz tatili için Sorin

1 Makalede Martı oyunundan yapılan tüm alıntılar için bkz:: Anton Çehov. Bütün Oyunları II. Çev.: Ataol Behramoğlu. (İstanbul: Türkiye İş Bankası Kültür Yayınları, 2002). 
çiftliğine gelişleri Medvedenko, Maşa, Treplev, Nina, Polina, Sorin ve Şamrayev için ateşleyici güç oluşturur:

\section{Perdede Alt Tekrar Eksenleri:}

Oyunun birinci perdesindeki temel tekrar ekseninin "Arkadina ve Trigorin'in çiftliğe gelmeleri” olduğu, söz konusu temel tekrar ekseninin, ateşleyici güç olarak Medvedenko’yu birinci perdede "Nina - Treplev birlikteliğine özenmeye" taşır. Oyunun hemen başında kişiliğine dair ipuçları veren Medvedenko, zor bir hayatın içine doğmuş olmasına karşın dirençli ve azimli bir köy öğretmenidir. Onu, ailesini geçindirmekle yükümlü kılan hayatın gerçeklerlerinin farkındadır: Nina ile Treplev'in birbirlerine aşık olmaları ve bu aşkın tiyatro sahnesinin üstünde de sürmesine özenmesine rağmen, Maşa ile kendisinin böyle bir uyum içinde olmadıklarının da farkındadır. Aynı zamanda, Maşa'yı görmek için her gün çiftliğe yürürken, kendisine geri dönüşü için at verilmeyeceğini bilir. Aynı yolu yürüyerek geri dönmeyi, köy öğretmeni olmanın zor koşullarını kabullendiği gibi kabullenmiştir. Nina ve Treplev'in sanatsal birlikteliğinden hareket eden Medvedenko, aynı uyumu Maşa ile yakalamaya çalışmak ister ama karşılık bulamaz. Bu noktada Medvedenko'nun özendiği birlikteliğin taraflarından biri olan Nina karakterinin ne denli uzağında olduğu da saptanabilir. Öyle ki, oyunun ne birinci perdesinde ne de diğer perdelerinde Nina ile Medvedenko hiç konuşmazlar.

Sorin çiftliğinin kahyası Şamrayev'in kızı olarak doğan Maşa, babası gibi çökmek üzere olan feodal sınıfın değerlerine sahip çıkacak yaşanmışlıkta değildir. Ancak bir kent insanı da olmayışı Maşa'yı kimliksiz, geçmişsiz ve geleceksiz bir oyun kişisi kılar. Maşa'nın oyun boyunca Treplev'e olan aşkından doğan duygusal açmazdan sıyrılamayışının göstereni, oyunun hemen başındaki "Hayatımın yasını tutuyorum. Mutsuzum.” repliğidir. Maşa'nın bu perdedeki yönelimi olan "Treplev'e olan aşkını Dorn'a açıklamak" "geçmiş", "mutsuzluk", "aşk", "para" ve "tiyatro" tekrarlarıyla gerçekleşir.

Oyunun temel tekrar ekseninde, birinci perde için Sorin'in yönelimi "yazarlık hayallerinin hatırlamak" üzerine kuruludur. Sorin, hayatının önceki dönemlerini şehirde geçirmiş, emekli olduğunda, artık çiftliğin onu şehirde yaşatmak bir yana, emekli maaşını bile tüketecek duruma gelmesi yüzünden çiftlikte yaşamak zorunda kalmıştır. Oyunun birinci perdesinden başlayarak hayatta hedeflediği hiçbir şeyi gerçekleştiremediğinden şikayet eder: Evlenmek istemiştir ancak kadınlardan karş1lık bulamamıştır, yazar olmak istemiştir ancak bu da gerçekleşmemiştir. Kente yaşamak istemesine karşın, parasal durumu el vermediğinden çiftlikte yaşamaya mecbur kalmıştır. Yaşl1lığın getirdiği hastalıklara Dorn'dan talep ettiği ilaçlarla direnmeye çalışır. Aynı biçimde sağlığı, maddi 
durumu ve yaşı el vermese de kente gitmek için direnç gösterir. Bu noktada Sevda Şener'den aşağıdaki alıntıyı yapmak yerinde olur:

Çehov'un kişileri, toprak köleliğinin kaldırıldı̆̆ı, orta sınıfın güçlendiği, ticaretin geliştiği, para kazanma tutkusunun ateşlendiği, endüstrileşmeye adım atıldığı, değer yargılarının değiştiği bir dönemde yaşamlarını sürdürmeye çalışan mülk sahibi toprak soylularıdır. İyi eğitim görmüş, güzel alışkanlıklar edinmiş, rahat yaşamaya alışmışlardır. Gördükleri eğitim onlara sıradan insanların üstünde bir ahlak düzeyi, bir artı duyarlık, bir zevk inceliği sağlamıştır. Fakat hazır yemeye ve rahata alışmış olduklarından çalışmayı, topraklarını işletmeyi beceremezler, ellerindekini yitirme tehlikesi yaşarlar, ya da tümüyle yitirirler, yoksul düşerler. İşte toplumdaki değişim sürecine denk düşen bu bireysel değişim süreci içinde bir insanlık dramı yaşanır. $\mathrm{Bu}$ insanlar, toplumdaki ekonomik değişime koşut olarak değer yargılarının da değişmekte olduğunu görmek zorunda kalmışlardır. Yoksullaşmaya katlansalar da bağlandıkları değerlerden ödün vermemeye direnirler.1

Sorin çiftliğindeki hareketsiz hayat, Arkadina ve Trigorin'in gelişiyle geçici bir hareketlenme yaşar. Bu hareketlenmenin Sorin'deki karşıllğ̆ yazarlık hayalleri kurarak geçirdiği gençlik yıllarındaki bu hevesinin tekrar su yüzüne çıkması olur. Kız kardeşi Arkadina'nın sevgilisi Trigorin'in popüler bir yazar olması, yeğeni Treplev'in yazdığı oyunun seyirciyle buluşmak üzere olması Sorin'in hevesinin su yüzüne çıkmasını hızlandıran etkenler olur. Sorin'in bu perdede "sağlı" alt tekrar ekseninde yer alan "Dün saat onda kafayı vurup yattığımda, ya da bu sabah dokuzda kalktığımda hep aynı duygu vardı içimde: sanki çok uzun süren bir uyku yüzünden benim kafa tasıma yapışmış da falan filan... Öğle yemeğinden sonra da elimde olmaksızın yatıp uyudum yine, ama kafamın içi kazan gibi, vesselam..." göstereni, çiftlik hayatının uzun süren bir uykunun ardından şehirden gelenlerin etkisiyle uyandığının göstergesidir.

Oyunun temel tekrar ekseninde, birinci perde için Treplev'in yöneliminin "yazar olma isteği”" üzerine kurulduğu saptanmıştı. Treplev, tıpkı Maşa gibi köye de kente de ait olmayan bir oyun kişisidir. Yenilikçi bir yazar olma yolunda kentte yaşaması gerekirken, ekonomik sıkıntılar nedeniyle üniversitenin üçüncü sınıfından ayrılmış, yine aynı nedenle dayısının yanında, çiftlikte yaşamak zorunda kalmıştır. Sahip olduğu entelektüel özelliklerle köye yabancı, annesinin soylu kimliğine uzaklığıyla şehre yabancıdır. Çocukluğundan bu yana Arkadina'nın şöhretinin ve başarısının gölgesinde kalan Treplev, çoğu zaman Arkadina'nın “yalnızca annesi” olmasını istemiş ancak annesinden yeterli ilgiyi hiçbir zaman görememiştir. Bu göstergenin göstereni olarak Treplev'in Hamlet oyunundan aktardığı replik verilebilir: "Öyleyse neden kötülüğe teslim ettin kendini, aşkl cinayetin uçurumunda aradın?” Oyunun birinci perdesinde annesinin Trigorin ile yaşadı̆̆ ilişkiden rahatsızlığını dile getirirken aynı zamanda annesinin, ona göre eskimiş tiyatro anlayışında diretmesinden de rahatsızdır. Aynı biçimde günün popüler yazarı Trigorin'in de yazma serüvenini 
eleştirir, yeni biçimlere gereksinim duyulduğunun altını çizer. Dayısı ile birlikte çiftlikte sürdüğü sessiz köy yaşamı Arkadina ve Trigorin'in çiftliğe gelmesi ile yazar olma yolundaki isteğini artırır. Kendisine hiçbir zaman beklediği ilgiyi göstermeyen annesine de, yapıtlarını eleştirdiği Trigorin'e de kendini yenilikçi bir yazar olarak ispatlamak ister. Ancak bu yolda yeterince dirençli davranacak güce sahip olmadığından her başarısızlıkta kendine ve ürettiklerine yönelir: Gölün karşı yakasındaki çiftlikte yaşayan, birinci perdede sahnelenen oyununun tek oyuncusu olan Nina’yı sevmektedir. Nina ile çalıştıkları oyunu annesinin alaylı tavrı yüzünden yarıda kesecek daha sonra oyun metnini yırtıp atacaktır. Treplev'in birinci perdedeki yönelimi olan "yazar olma isteği”ne "mutsuzluk", "aşk”, "sanat ile ilgi" ve "tiyatro" tekrarıyla ulaşılır.

Nina, annesinin ölümünden sonra üvey annesinin ve babasının baskıları altında gölün karşı yakasında yaşayan, aktris olmaya hevesli bir genç kızdır. Treplev'in sanat anlayışını, yeni biçim arayışlarını anlamadığını oyunun birinci perdesinden başlayarak dile getirir, Trigorin'in popüler eserlerine ve Arkadina'nın ününe hayrandır. Bu göstergenin en belirgin göstereni "Çok az hareket var oyunuzda, sadece okuma. Oysa bir oyunda bence mutlaka aşk olmalı” repliğidir. Tıpkı Maşa ve Treplev gibi Nina'da da oyun boyunca köy ve kent arasındaki sıkışmışlığın izleri sürülür. Sorin çiftliğine gelmesini onaylamayan anne ve babası yüzünden hep bir zaman sıkıntısı yaşar, kaçarcasına geldiği çiftlikten yine kaçarak ayrılır. Oyunun birinci perdesinde yakalanan bu durum oyunun sonunda yine tekrarlanacak, gizli gizli geldiği çiftlikten yine benzer bir biçimde kaçarcasına ayrılacaktır. Trigorin ve Arkadina'nın çiftliğe gelmelerinin ateşleyici gücüyle Nina'nın oyunun birinci perdesindeki yönelimi belirlenir: "Aktris olma isteği”. Üvey annesinin ve babasının baskısından kurtulmayı şehre gidip ünlü bir aktris olmaya denkleyen Nina, Trigorin'e ve Arkadina'ya olan hayranlığının da yardımıyla oyunun birinci ve ikinci perdelerinde şehre gidip ünlü bir aktris olma hayalleri kuracak, üçüncü perdenin sonunda şehre gidecek ancak ikinci sınıf bir oyuncu olmayı başarabilecektir. Nina'nın birinci perdedeki "aktris olma isteği” yönelimine "aşk", "sanat ile ilgi”, "şöhret”, "aile”, "tiyatro" ve "zaman" alt tekrar eksenleriyle ulaşılır.

Polina'nın oyunun birinci perdesindeki yönelimi "Dorn'a olan aşkının su yüzüne çıkması" olarak belirir. Polina, Sorin çiftliğinin kahyası Şamrayev'in karısıdır. Kocasının davranışlarından bıkmış, aşık olduğu Doktor Dorn'un onu Şamrayev'den kurtaracağına inanmıştır. Dorn ise, tıpkı, Polina, Şamrayev ve Sorin gibi var oluşunu geçmişle belirlemiştir. Bir zamanların gözde doktoru olarak şimdide var olamayacağının bilincinde olduğu göstergesinin gösterenleri "Bende her şeyden önce becerikli bir hekimi sevdiler. On- on beş yıl kadar önce bütün bu il çevresinde, anımsayacaksınız, doğru dürüst tek doğum hekimi bendim.", “ Yaşım elli beş.", "Söz etme gençliğimi mahvettiğinden..." ve "Ah gençlik, gençlik!" replikleridir. Oyunun şehirde yaşamayan kişilerinin bugünü geçmişin 
tekrarı gibi algıladıkları noktasından bakıldığında Polina'nın "Aşk" alt tekrar ekseniyle ulaştığı yönelimin yaşına ve yaşadığı anın gerçeklerine olan uzaklığının göstergesi niteliğindedir. Polina, tıpkı oyunun şehirde yaşamayan görece yaşlı kuşağının temsilcileri kocası Şamrayev ve aşığı Dorn gibi, geçmişi bugünde yaşatmakta kararlı, geçmişin geçmişte kaldığı gerçeğini kabul etmemekte israrlıdır. Polina'nın birinci perdedeki yönelimine "aşk" tekrar ekseniyle ulaşılır.

Oyunun geçmişi bugünde yaşatmayı seçmiş bir diğer oyun kişisi olan Şamrayev'in birinci perdedeki temel yönelimi, Arkadina ve Trigorin'in gelişiyle "tiyatroyla ilgili anılarının canlanması" üzerinedir. Şamrayev'in geçmişle bağları o denli sıkıdır ki, varlık nedeni olan "kahyalık statüsünü" kaybetmemek adına, feodal düzenin çöküşünü bile yok sayar. Bugünde varlığını sürdürme savaşı veren Arkadina'ya oyunculuğu bırakmış eski ünlü oyuncular hakkında sorular sorması söz her iki oyun kişisine ait konusu göstergenin göstereni olarak karşımıza çıkar:

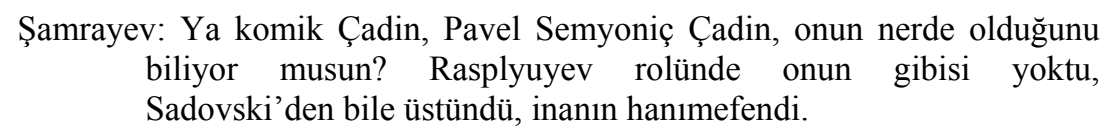

Arkadina: Durmadan bir takım Nuh nebiden kalma şeyleri sorup duruyorsunuz. Nerden bileyim canım!

Şamrayev'in geçmişi bugünde yaşatma çabası, tıpkı Arkadina'nın bugünde varlı̆̆ını sürdürme çabası gibi diğer oyun kişileri için kimi zaman gülünç, ama çoğunlukla zor zamanlar tarif eder.

Şamrayev'in birinci perdedeki temel yönelimine "Geçmiş" ve "Sanat ile İlgi” tekrarlarından ulaşılır.

2. Perdede Temel Tekrar Ekseni :

Gitmek ve Gelmek : Arkadina'nın alışverişe gitmek istemesi üzerine Şamrayev'in at vermemesi.<smiles>C[14C](C)[14CH3]</smiles>

Arkadina: Şehre dönme kararı.

Sorin: Arkadina’yı vazgeçirmeye çalışması.

Nina: Trigorin'le yakınlaşmak.

Trigorin: Nina'ya umut vermek.

Treplev: Trigorin - Nina yakınlaşmasını kıskanmak.

2. Perde Temel Tekrar Ekseni:

Gitmek ve Gelmek : Arkadina'nın alışverişe gitmek istemesi üzerine Şamrayev'in at vermemesi.

İkinci perdenin temel tekrar ekseni Arkadina'nın alışveriş yapmak için Polina'yla şehre gitme isteği üzerine Şamrayev'in at vermemesi olarak belirlenir. Bu temel tekrarın ateşleyici gücü Arkadina'nın şehre dönmeye karar vermesiyle karşılık bulur: Şamrayev'e kızan Arkadina'nın şehre 
dönme kararı ikinci perdenin tümüne hakim olurken, Arkadina bu kararından vazgeçtiğini ikinci perdenin sonunda duyurur.

\section{Perdede Alt Tekrar Eksenleri}

“Arkadina'nın alışverişe gitmek istemesi üzerine Şamrayev'in at vermemesi” temel tekrar ekseninin Arkadina'daki karşılığı şehre dönme kararı olur. Birinci perdede Arkadina için göstergeler ışığında saptanmış olan "bugünde varlığını koruma uğraşı" ikinci perdenin başından itibaren varlığını göstermeye devam eder. İkinci perdenin hemen başında Arkadina, kendine on beş yaşında kız rollerine çıkacak kadar iyi baktığının altını çizer. Hemen arkasından yaz tatili için geldikleri çiftliğin sakinliğinden ne kadar sıkıldığından, çiftlikte olmak yerine otel odasında rolüne çalışmayı yeğleyeceğinden dem vurur. Arkadina'nın söz konusu çabasının ikinci perdedeki en belirgin göstergesi "Sonra, bir de kuralım vardır benim: İleriye bakmamak... Ne yaşlıllğg ne de ölümü getiririm aklıma... Her şey olacağına varır." gösterenidir. Bu perde de birinci perde de olduğu gibi Şamrayev'in "geçmişi bugünde yaşatma çabasıyla", Arkadina'nın "bugünde varlığını sürdürebilme çabası” çatışır. Alışverişe gitmek isteyen Arkadina'ya at vermeyen Şamrayev, onun öfkelenerek şehre dönme kararı almasina neden olur.

Sorin'in ikinci perdedeki temel yönelimi, Şamrayev'e kızan Arkadina'yı şehre dönme karanından vazgeçirmek üzerine kuruludur. Söz konusu perde Şamrayev ile Sorin arasındaki ekonomik ilişkinin altının en belirgin biçimde çizildiği perdedir. Çiftliğin sahibi olan Sorin, gelinen noktada bir anlamda kendi çıkarlarını da göz ardı eden bir umursamazlık içindedir. Bu durumun en belirgin göstereni birinci perdede Sorin'in “Köpek havllyor yine... Illya Afanasyeviç, çok rica ederim çözdürün şu hayvanı." repliğine karşılık Şamrayev'in “Olamaz Pyotr Nikolayeviç, ambara hırsız girmesinden korkarım. İçerde darı var.” karşılığıdır. Şamrayev, Sorin'in şehirde yaşadığı uzun yıllar boyunca Sorin çiftliğini yönetmiştir, bugün de çiftlik yönetimi ile ilgili bir şey söz konusu olduğunda herkese, hatta çiftliğin sahibi olan Sorin'e bile düşmanca tavırlar geliştirmektedir. Ancak, Sorin, Şamrayev'in bu düşmanca tavrına ve emekli maaşının boşa gittiğini düşünmesine rağmen Şamrayev'in varlığına karşı koyamaz. İkinci perdenin temel tekrar ekseninin ateşleyici gücüyle şehre dönme kararı alan Arkadina'yı vazgeçirmeye çalışan Sorin, Arkadina’yı bu karardan döndürmeyi başaracak ancak Şamrayev ile ilgili yine başarılı olamayacaktır. Bu durumun önsemesi Dorn tarafından yapılır: "Kocanı yakasından tutup atmak gerek aslında. Fakat şöyle bağlanacak iş: Pyotr Nikolayeviç moruğuyla saygıdeğer kız kardeşi gidip özür dileyecekler ondan. Göreceksiniz bakın."

Nina’nın ikinci perdedeki yönelimi “Trigorin ile yakınlaşmak” olarak belirlenir. İkinci perdeye hakim olan Arkadina'nın çiftlikten ayrılma kararı, Nina'nın Trigorin ile yakınlaşmasına sebep olacak, bu kararın etkisiyle Nina kendisine umut veren Trigorin'e yönelecektir. Trigorin ile yaptığ 
uzun konuşmadan önce, bir martı vurmuş olarak yanına gelen Treplev ile bir konuşma yapar. $\mathrm{Bu}$ konuşmada, birinci perdede Treplev'in sanat anlayışını, yeni biçim arayışlarını anlamadığını, Trigorin'in popüler eserlerine ve Arkadina'nın ününe hayran olduğunun altını çizer gibidir. Bu göstergenin göstereni “Sizi anlayabilmek için fazla basitim.” repliğidir. Birinci perde de saptandı̆̆ gibi Nina, annesinin ölümünden sonra üvey annesinin ve babasının baskıları altında gölün karşı yakasında yaşayan, aktris olmaya hevesli bir genç kızdır. Şöhret olma hevesi, onu kolayca anlamadığı biçim denemeleri yapan Treplev'den Trigorin’e yöneltecektir. Nina'nın söz konusu göstergeler 1şığındaki yönelimine "mutluluk", "birilerinin birilerini anlatması" ve "şöhret" alt tekrar eksenleriyle ulaşı1ır.

Trigorin'in ikinci perdedeki yöneliminin “Nina’ya umut vermek” olduğu saptanır. Şamrayev’e öfkelenen Arkadina'nın çiftlikten ayrılıp şehre dönme kararı Trigorin’i, bir daha karşılaşamayacağını düşündüğü Nina ile içten bir konuşmaya yöneltir. Gençliğini editör kapılarında heba ettiğini, bunun sonucunda üne kavuşmuş olmasına rağmen huzursuz olduğunun altını çizer. Bu huzursuzluk onu sürekli yazmaya, yeni yapıtlar için notlar almaya zorlar. Bütün bunlardan sıyrılıp, sakin bir göl kıyısında balık tutmayı özlediğini dile getirdiği noktada gençliğinde bir yazar olarak tutunabilme savaşı içinde hiç yaşamadığı bir aşka, Nina’ya göz kırpar.

Treplev'in ikinci perdedeki yönelimi “Trigorin - Nina yakınlaşmasını kıskanmak” olarak belirlenir. Birinci perdede sahnelenen oyununu, annesinin alaylı tavırları yüzünden kesmesinin ardından uzaklaşan, geri dönüğünde Dorn'dan başka kimseyi bulamayan Treplev, birinci perdenin sonunda evine döndüğünü öğrendiği Nina’nın peşinden gider. İkinci perdede ise elinde vurulmuş bir martıyla döndügünde Nina'yı çoktan Trigorin'e yönelmiş olarak bulur. Oyunun birinci perdesinde dayısı ile birlikte çiftlikte sürdüğü sessiz köy yaşamı Arkadina ve Trigorin'in çiftliğe gelmesi ile yazar olma yolundaki isteğini artırmış, kendisine hiçbir zaman beklediği ilgiyi göstermeyen annesine de, yapıtlarını eleştirdiği Trigorin'e de kendini yenilikçi bir yazar olarak ispatlamak istemiştir. Ancak bu yolda yeterince dirençli davranacak güce sahip olmadığından her başarısızlıkta kendine ve ürettiklerine yönelir: Birinci perdede Nina ile çalıştıkları oyunu annesinin alaylı tavrı yüzünden yarıda keser. Bu tavrın ikinci perdedeki yansıması da oyun metninin tümünü yırtıp attığını söylemesi olur. 


\section{2. ve 3. Perdenin Arasında Kalan Ara Zamanda Temel Tekrar Ekseni:}

Gitmek ve Gelmek : Arkadina'nın çiftlikte kalma kararı.

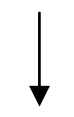

Ateşleyici Unsur $\longrightarrow \quad$ Treplev: Treplev'in Trigorin'i düelloya davet etmesi ve
intihar girişimi.

Oyunda yer almayan, ancak oyunun ikinci ve üçüncü perdesi arasında yer alan "ara zaman" dilimi, ikinci perdenin sonunda Arkadina'nın şehre dönme kararından vazgeçmesi ile yaşananları kapsar. Üçüncü perdede serimlenecek olan gelişmelerin ana tekrar ekseni “Arkadina'nın şehirde kalma kararı” olarak belirlenir. Söz konusu ana tekrar ekseni, Treplev'de iki perde arasında karşıl1k bulur. Treplev, ikinci perdede "Trigorin - Nina yakınlaşmasını kıskanmak" yönelimine koşut olarak, iki perde arasında Trigorin'i düelloya çağırır ancak, düello engellenince de öfkelenerek kendini vurur. Treplev, söz konusu "ara zaman" dilimde de birinci ve ikinci perdedeki yönelimlerini pekiştirecek bir tutumla, önüne çıkan her engelden sonra kendine ya da ürettiklerine yönelir. Birinci perdede, annesinin alaycı tavırları yüzünden oyununu yarıda keser, ikinci perdede oyunun bir tek parçasını bile bırakmamacasına yırtıp attığını söyler. "Ara zaman” olarak adlandırılan bu dilimde ise, yaşadıkları zamanda artık bir geçerliliği kalmadığı açık olan "düello" fikrine öne sürerek Trigorin ile çarpışmak ister; gerçekleştiremeyince de öfkelenerek kendini vurur. Oyunun ikinci ve üçüncü perdelerinin arasında kalan "ara zaman" diliminde de gelmek / gitmek ana tekrar ekseni hakimdir. Arkadina'nın şehre dönme kararından vazgeçmesi, Trigorin - Nina yakınlaşmasını kıskanan Treplev'in önce düello teklifine, sonra da kendisini vurmasına neden olur. Bu göstergenin gösterenlerinin izleri üçüncü perdede sürülecektir. 
Gitmek ve Gelmek : Şehre dönüş.

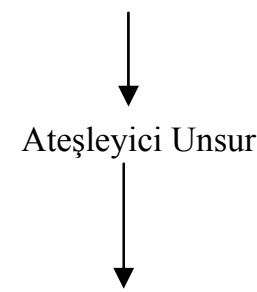

Maşa: Medvedenko'yla evlenme kararı alır.

Sorin: Arkadina ve Trigorin ile birlikte şehre dönmek ister.

Treplev: Annesi ile sanat anlayışları ve ilişkileri üzerine tartışır.

Trigorin: Nina'yla birlikte olabilmek için çiftlikte kalmak ister.

Arkadina: Trigorin'i, Nina'dan vazgeçirmeye çalışır.

Nina: Oyuncu olmak için evden kaçmaya karar verir.

\section{Perdede Temel Tekrar Ekseni :}

Gitmek ve Gelmek : Arkadina ve Trigorin'in şehre dönüşü.

Oyunun her perdesinde gelip gidişleriyle bir temel tekrar ekseni oluşturan Arkadina ve Trigorin, üçüncü perdede "şehre dönüş”leriyle söz konusu ekseni oluştururlar. Arkadina ve Trigorin'in şehre dönüşlerinin hakim olduğu üçüncü perde, oyunun tansiyonu en yüksek perdesidir, bir anlamda çiftliğe gelişleriyle yarattıkları hareketlenmenin en sıcak görüldüğü perdedir. Öyle ki, ilk perdede çiftliğe gelişleriyle, uzun zamandır sessiz sedasız kır yaşamını sürdüren diğer oyun kişilerinin hayatına, kendi "kentli hayatlar"ını taşımışlar, diğer oyun kişileri için ateşleyici güç oluşturmuşlardır. Gelişleriyle hareketlendirdikleri çiftlikten ayrılıyor olmaları doğal bir gerilimi de beraberinde getirir. Üçüncü perdedeki "şehre dönüş” ana tekrar ekseni Nina, Trigorin, Arkadina, Treplev, Maşa ve Sorin için yeni yönelimler belirler.

\section{Perdede Alt Tekrar Eksenleri:}

Oyununun üçüncü perdesinde Maşa'nın temel yönelimi “Medvedenko’yla evlenme kararı” üzerine kuruludur. İlk iki perdede Treplev’e olan aşkını açık bir biçimde gördüğümüz Maşa, üçüncü perdenin hemen başında Trigorin'le yaptığı konuşmada Medvedenko'yla evlenme kararı aldığını söyler. İkinci perde ile üçüncü perde arasında kalan "ara zaman” diliminde, Treplev'in kendisini vurmuș olduğu üçüncü perdenin bașında Mașa'nın ağzından duyulur. Trigorin, Treplev'in bașarısız intihar girişimini ve kendisini düelloya çağııışını, Treplev'in yazarlık serüvenine bağlar. $\mathrm{Bu}$ göstergenin göstereni Trigorin'in “Bir bakmışsın kendini vurmuş, şimdi de beni düelloya çağıracağı söyleniyor. Niçin bütün bunlar? Somurtuyor, homurdanıyor, yeni biçimler vaaz edip duruyor... Oysa herkese yer var. Ne diye itişip kakışmalı ki? ” repliğidir. Oysa Maşa, Trigorin - Nina yakınlaşmasının 
farkında olduğu gibi, Treplev'in de bu yakınlaşmanın farkında olduğunun bilincindedir. $\mathrm{Bu}$ göstergenin göstereni Trigorin'e verdiği yanıtta yer alır: "Kıskançlık da var işin içinde..." Treplev'in kendini vurmasından sonra Maşa Medvedenko'yla evlenme kararı alır. Bu yönelime "Gelecek", "Aşs", "Mutsuzluk", "Kendini Kendi Gözleriyle Yargılama", "Birilerinin Birilerini Anlatması", "Para" alt tekrar eksenleriyle ulaşılır.

Sorin'in üçüncü perdedeki yönelimi “Arkadina ve Trigorin ile birlikte şehre dönmek istemesi” üzerine kuruludur. Sorin, oyunun birinci perdesinden başlayarak altmış yaşına geldiği halde hayatta hedeflediği hiçbir şeyi gerçekleştiremediğinden şikayet eder: Evlenmek istemiştir ancak kadınlardan karşılık bulamamıştır, yazar olmak istemiştir ancak bu da gerçekleşmemiştir. Kente yaşamak istemesine karşın, parasal durumu el vermediğinden çiftlikte yaşamaya mecbur kalmıştır. Yaşlılığın getirdiği hastalıklara Dorn'dan talep ettiği ilaçlarla direnmeye çalışır. Bu göstergelerden hareketle Sorin'in tıpkı Arkadina gibi varoluşunu bugünde sürdürmekten başka çıkışı olmadığı saptanır. Birinci perdede Arkadina ve Trigorin'in gelişleriyle hareketlenen köy yaşamı üçüncü perdede Sorin'i onlarla birlikte şehre gitmeye yöneltir. Bu noktada kız kardeşi Arkadina'yla yaptığı konuşmada her ikisinin de bugünde var olma çabaları çatışır. Onlar gittikten sonra çiftlikte yaşayamayacağını, kentte yaşamak istediğini söyleyen Sorin'e, Arkadina, oyunda para sahibi tek kişi olarak yine yardım elini uzatmayacaktır. Gelecekten hiçbir beklentisi olmayan Sorin, bugünde varolabilmek için kente yaşamalıdır, kentte yaşamak için de paraya gereksinim duyar. Ancak Arkadina, "göz önünde olan ünlü bir oyuncu" olarak kendi masraflarını ancak karşılayabildiği savıyla oğluna da kardeşine de para vermez. Sorin aynı konuşma içinde Treplev'in de parayı olan gereksiniminden söz edecek ama aynı biçimde reddedilecektir:

"Sorin: Bence... Ona biraz para vermen yapılacak en iyi şey olurdu. Bir kere, doğru dürüst giyinmesi gerek, vesselam... Baksana üç yıldır aynı ceketi taşıyor sırtında, paltosu da yok... Sonra biraz gezip tozması da fena olmazdı delikanlının... Yurtdışına gitmesi filan... Çok para tutmaz bu."

"Arkadina: Tutmaz olur mu.... Kostüm için bir şeyler yapabilirim belki, fakat yurtdışı olmaz... Yok, şu sıra kostüm de olamaz. Param yok!”

Oyunun üçüncü perdesindeki temel tekrar ekseninin “Arkadina ve Trigorin'in çiftlikten ayrılışları" olduğu, söz konusu temel tekrar ekseninin, ateşleyici güç olarak Treplev’i üçüncü perdede “annesi ile sanat anlayışları ve ilişkileri üzerine tartışmaya" taşıdığı belirlenmişti. Üçüncü perdede de hem annesi ile ilişkisi, hem sanat anlayışları hem de annesinin Trigorin'le yaşadığg ilişkiden duyduğu rahatsızlık ile ilgili bir konuşma yapar. Treplev, çocukluğundan bu yana Arkadina'nın şöhretinin ve başarısının gölgesinde kalmış, çoğu zaman Arkadina'nın “yalnızca annesi” olmasını istemiş, ancak annesinden yeterli ilgiyi hiçbir zaman görememiştir. Annesinin yanına küçük bir çocuk gibi sargısını 
değiştirmesi ricası ile gelişi göstergenin bir diğer göstereni olarak belirir. Oysa Arkadina, Treplev'in annesini "yalnızca annesi” olarak hissettiği çocukluk anılarının bir kısmını hatırlamıyordur bile:

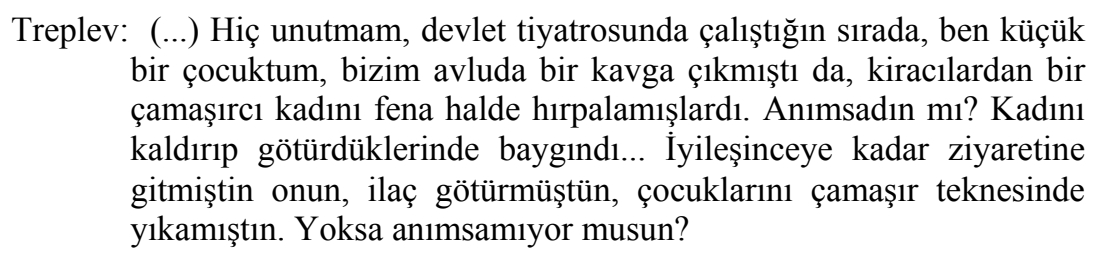

Arkadina: Hayır!

Treplev, oyunun birinci perdesinde annesinin Trigorin ile yaşadığı ilişkiden rahatsızlığını dayısı Sorin'e dile getirmişti. Üçüncü perdede ise bu ilişkiden duyduğu rahatsızlığı dile getirirken aynı zamanda annesinin, ona göre eskimiş tiyatro anlayışında diretmesinden de rahatsızlığını da gündeme getirir. Günün popüler yazarı Trigorin'in de yazma serüvenini eleştirir, yeni biçimlere gereksinim duyulduğunun doğrudan annesine söyler. Treplev'in söz konusu rahatsızlıklarından doğan tartışmayı Arkadina sadece Treplev'in basit kıskançlığına bağlayacak, oğlunun beklediği ilginin yakınından bile geçmeyecektir. Treplev'in beklediği ilgi ve sevgiyi yine göremediğinin farkında oluşu "Sargıyı doktor sarar artık." repliğiyle verilir.

Bu konuşma içinde Treplev, tıpkı dayısı Sorin'in onun gereksinimleriyle ilgili Arkadina'ya talepte bulunması gibi, Treplev de dayısının şehirde yaşaması için annesinden yardım ister. Dayısının sağlığından endişe eden Treplev, annesine Sorin'in şehirde yaşaması için para vermesini ister, Arkadina ağabeyini reddettiği gibi Treplev'i de başarıyla reddedecektir: " Param yok benim, aktrisim ben, banker değil..."

Oyunun temel tekrar ekseninde, üçüncü perde için Trigorin'in yöneliminin "Nina'yla birlikte olabilmek için çiftlikte kalmak istemesi” üzerine kurulduğu saptanmıştı. Üçüncü perdenin hemen başında, Nina, Trigorin'e üzerine Trigorin'in adının baş harflerini ve "Gündüzler ve Geceler" adlı kitabının adını kazıttığı bir madalyon hediye eder. Bu hediye bir de mesajı da barındırır içinde: Trigorin'in söz konusu kitabından sayfa ve satır numaraları verilmiştir. Trigorin, Arkadina'yla konuşmadan önce bu sayfa numaralarının ve satırların hangi mesaja denk düştügünü bulur ve Arkadina'ya kalmak istediğini söyler: "Ĕger bir gün hayatım sana gerecek olursa gel ve al onu..." Birinci ve ikinci perdede Trigorin'in gençliğini editör kapılarında heba etmesinin sonucunda hatırı sayılır bir üne kavuşmuş olmasına rağmen huzursuz olduğunun üzerinde durulmuştu. Bu huzursuzluk, önceki perdelerde yaşamak için sürekli yazmak zorunda olması ve gelecek kuşaklara taşınacak kadar güçlü bir yazar olmadığının farkında oluşuna bağlıdır. Ancak üçüncü perdede Trigorin, gençliğindeki koşuşturma yüzünden gerçek aşkı hiç yaşamayışına isyan eder. Kendisine hayatını sunan genç kızla bir aşk yaşamak ister. Ancak Arkadina, Nina ile aşk yaşamak istediğini açıkça söyleyen Trigorin’e 
bugünde varolma gerçeklerini hatırlatacak ve Trigorin'i bu hayalden vazgeçirmeyi başaracaktır. Arkadina ve Trigorin'in çiftlikten ayrılmalarından hemen önce Nina'nın, evden kaçıp aktris olmak için Moskova'ya gideceğini söylemesi sadece bir rastlantıdır. Trigorin, Arkadina'nın ne demek istediğini çok iyi anlamış biri olarak bu rastlantıyı yaşanması muhtemel bir kaçamak firsatı olarak değerlendirir, Nina'ya Moskova'da buluşmak için bir adres verir. Trigorin'in bu perdedeki yönelimine "Mutsuzluk", “Aşk" ve "Kendini Kendi Gözleriyle Yargılamak” tekrarlarıyla ulaşılır.

Arkadina’nın üçüncü perdedeki yönelimi “Trigorin'i Nina'dan vazgeçirmeye çalışmak” üzerine kuruludur. Arkadina'nın bugünde varolma çabası diğer perdelerde de saptanmış, tüm yönelimlerinin bugünde varolma savaşına işaret ettiği belirtilmişti. Üçüncü perdede, sevgilisi Trigorin'i Nina’ya kaptırmak üzere olduğunu anladığı noktada büyük bir savaşa girer. Ancak bu savaş, aşkı için mücadele eden aşık bir kadının savaşı olmaktan çok uzaktır. Arkadina, yine statüsünü sağlam tutmak adına savaşır. Nina ile birlikte olmak için kendisinden açıkça izin isteyen sevgilisine ilk tepkisi, "yaşlanma", "bir başka kadın için arka plana itilme" ve "şöhretini tehlikeye düşürme" bağlamlarında olur. Kendisini anlayışlı olmaya davet eden Trigorin'e ikinci tepkisi daha sert olur. Yaşamak için durmadan yazmak zorunda olan Trigorin'in, ancak kendisi tarafindan anlaşılabileceğini, onun değerini kendisi kadar kimsenin anlayamayacağını söyler. Bu, Trigorin için açık bir tehdit oluşturur: Gençliğinde hiç tatmadığı duygular için son kozunu oynayan Trigorin karşısında Arkadina, kendisinin desteği olmadan Trigorin'in bugünde varolmasının kolay olmayacağı kozunu oynar. Arkadina'nın tehdidine hemen boyun eğen Trigorin, Nina ile birlikte olmaktan da vazgeçerek, Arkadina'yla şehre dönmeye karar verir. Bu sahne aynı zamanda bugünde varolma savaşı sürdüren iki oyun kişisinin birbirlerinin varlıklarından nasıl faydalandıklarını da gösteren bir sahnedir. Arkadina'nın bu perdede “Trigorin'i Nina'dan vazgeçirmeye çalışmak” yönelimine "Gelecek” "Mutsuzluk" “Aşk” Birilerinin Birilerini Anlatması”, "Sanat ile İlgi” alt tekrar eksenleri ile ulaşılır.

Nina’nın üçüncü perdedeki yönelimi "Oyuncu olmak için evden kaçmaya karar vermek" üzerine kuruludur. Oyunun birinci perdesinden başlayarak, yaşadığı baskı dolu köy yaşamından kurtulmanın yolunu ünlü bir aktris olmaya denkleyen Nina, ikinci perdede hayranı olduğu Trigorin ile yakın bir sohbet firsatı yakalamış, üçüncü perdenin başında ise ona tüm hayatını vermeye hazır olduğunu imleyen bir mesaj vermiştir. Söz konusu perdenin sonunda ise bastonunu unutan Trigorin'in eve dönmesi sonucunda karşılaşırlar. Arkadina'nın bugünde varolabilmek için onunla birlikte olmak zorunda olduğunu hatırlatması üzerine, Nina'dan hemen vazgeçen Trigorin, bu rastlantıdan faydalanır. Oyuncu olmak niyetiyle evden kaçmaya, Moskova'ya gitmeye karar verdiğini söyleyen Nina, buluşmak üzere Trigorin'den adres alır. Nina için bir “ilişki”nin, Trigorin için bir "kaçamak"ın başlangıcı sahne sonunda öpüşmeleriyle verilir. 
Üçüncü perdenin temel tekrar ekseni "şehre dönüş" üzerine kuruludur. Bir başka deyişle, oyunun ilk perdesinde çiftliğe gelişleriyle uzun zamandır kendi hallerinde yaşayan kırsal kesim insanlarının hayatlarını hareketlendiren Arkadina ve Trigorin'in çiftlikten ayrılışları üçüncü perdenin tümüne hakimdir. Çiftliğe gelişleriyle diğer oyun kişileri için ateşleyici güçler oluşturan söz konusu kişilerin, çiftlikten ayrılmaları tansiyonu yüksek bir perdeyi beraberinde getirir. İlk iki perdede Treplev’e olan aşkını açık bir biçimde gördüğümüz Maşa, üçüncü perdenin hemen başında Trigorin’le yaptığı konuşmada Medvedenko'yla evlenme kararı alır. Ekonomik sıkıntılar nedeniyle kentte oturmak yerine çiftlikte yaşamak zorunda kalan Sorin'in sessiz kır yaşamı, ilk perdede Arkadina ve Trigorin'in gelişiyle hareketlenmiş, ikinci perdede Şamrayev'e sinirlenen kız kardeşini çiftlikte kalması için iknaya çalışmıştı. Üçüncü perde Sorin için bugünde varolmasının tek koşulunun şehirde yaşamak olduğunu kesin olarak anladığı ve şehre dönme kararı aldığı sahnedir. Altmış yaşındadır, sağlığı bozuktur, parası yoktur ve çocuk sahibi değildir. Başka bir deyişle geleceksizdir. Dolayısıyla yaşadığ1 günü mümkün oldukça uzatmak, şehirde yaşamak dileğindedir. Buradan hareketle çiftlikten ayrılan kız kardeşi ve sevgilisiyle birlikte kente dönmek ister. Oyunun birinci perdesinden başlayarak annesinden yeterli sevgiyi göremediğini imleyen, annesinin ona göre eskimiş sanat anlayışında diretmesinden rahatsızlığını sezdiren ve yine annesinin günün popüler yazarı Trigorin ile yaşadığı ilişkiden incindiğini gösteren Treplev, üçüncü perdede annesiyle tüm bu sıkıntılarını içine alan bir tartışma yapar. Ne ki, Arkadina, bugünde statüsünü koruyabilme savaşımında Treplev'in rahatsızlık duyduğu davranışlardan hiçbirinden vazgeçemez. Ne oğluna bugüne kadar göstermediği ilgiyi gösterecek, ne sanat anlayışını tartışmaya açacak ne de, Trigorin'le çıkara dayalı ilişkisini kesecektir. Üstelik aynı savaşımının devamı olarak çiftlikte kalmak isteyen Trigorin'i Nina'ya kaptırmamak adın adeta Trigorin'le pazarlığa girişecektir. Üçüncü perdedeki temel tekrar ekseni olan "şehre dönüş”, babasının ve babasının tüm parasına el koyan üvey annesinin baskısından kurtulmak için aktris olma hayalleri kuran Nina'yı şehre gitme kararına yöneltir. Bu perdede Nina, Trigorin'e hayatını onun için feda edebileceği mesajını verecek, perdenin sonunda onunla Moskova'da buluşmak üzere sözleşecektir.

\section{Perdede Temel Tekrar Ekseni :}

Gitmek ve Gelmek : Trigorin ve Arkadina'nın Sorin'in hastalığı yüzünden çiftliğe gelişi.

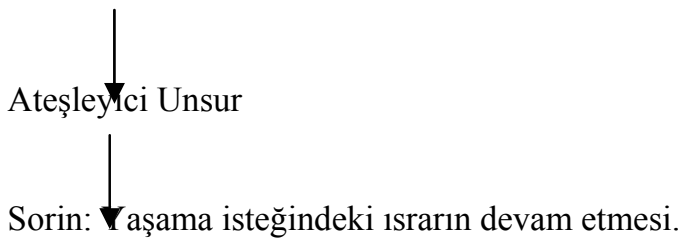

Trigorin: Treplev'e her ikisinin de yazısının bulunduğu dergiyi getirmesi.

Arkadina: Treplev'in yazdıklarını okuma fırsatı bulamadığını söylemesi.

Nina: Trigorin'i hala sevdiğini söylemesi.

Treplev: İntihar etmesi. 


\section{Perdede Temel Tekrar Ekseni :}

Gitmek ve Gelmek : Trigorin ve Arkadina'nın Sorin'in hastalığı yüzünden çiftliğe gelişi.

Oyunun her perdesinde gelip gidişleriyle bir temel tekrar ekseni oluşturan Arkadina ve Trigorin'in, oyunun dördüncü perdesinde de iki yıllık bir aradan sonra Sorin'in rahatsızlığ yüzünden çiftliğe gelmeleriyle, sakinleşmiş olan köy yaşamını yeniden hareketlenir. Üçüncü perdenin sonunda, Arkadina ve Trigorin'in Sorin çiftliğini terk edişlerinin üstünden geçen iki yıldan sonra dördüncü perde başlar. Birinci perdede Nina - Treplev birlikteliğine özenen Medvedenko, dördüncü perdede Maşa ile evlenmiş, bir de bebeği olmuştur. Ne ki, Maşa kocasıyla evinde değil, Treplev'i rahatça görebildiği Sorin çiftliğindedir. Oyunun başında sevdiği kızı görebilmek için altı verst yolu yayan gelen Medvedenko, oyunun sonunda bu kez karısı olmuş Maşa'yı alıp evine götürebilmek için aynı yolu yürümektedir. İlk perdede "soğuk bir umursamazlıktan fazlasını" göremediğine üzülen Medvedenko, son perdede evde aç olduğunu düşündüğü bebeğine rağmen Maşa'yı eve gelmeye ikna edememekte, üstelik soğuk bir umursamazlıktan fazlasını görmektedir. Öyle ki, Maşa, Medvedenko'yu çekilmez bulduğunu artık açıkça ona söylemektedir.

Üçüncü perdenin başında Medvedenko'yla evlenme kararı alan Maşa, Treplev'e olan sevgisini yüreğinden sökeceğini söyler, ancak dördüncü perdeye gelindiğinde Treplev'e olan aşkından doğan duygusal açmazdan sıyrılamamış olduğu görülür. Bu bağlamda, üçüncü perdede Trigorin ile yaptığı konuşmayla, dördüncü perdede Polina ile yaptığı konuşma birbirinin tekrarı niteliğindedir:

\footnotetext{
Maşa: İşte silkindim ve kararımı verdim: $\mathrm{Bu}$ aşkı söküp atacağım yüreğimden, kökünden sökeceğim. (...) Umutsuzca sevmenin, yıllardır bir şeyler bekleyip durmanın anlamı var mı? Evlenince aşk maşk kalmayacak, yeni kaygılar eski duyguları silip süpürecektir.. Sonra bir değişikliktir ne de olsa.
}

Maşa: (...) Kocamı başka bir yere atayacaklarmış zaten. Hele gideyim oraya, unutacağım her şeyi, kökünden söküp atacağım yüreğimden.

Oyunun ilk perdesinde çiftliğe gelişleriyle Sorin'e yazarlık hayallerini hatırlatan Arkadina ve Trigorin, üçüncü perdede Sorin'in onlarla birlikte şehre gelmek istemesine neden olurlar. Hiçbir gelecek umudu olmaması yüzünden bugünde varlığını uzatmak istediği önceki perdelerde saptanmış olan Sorin, dördüncü perdede de hasta yatağında aynı isteğini sürdürecektir.

Arkadina ve Trigorin, birinci perdedeki gelişleriyle Polina'nın Dorn'a olan aşkınının su yüzüne çıkmasına neden olmuşlar, birlikteliklerinin etkisiyle Polina, yaşına ve yaşadığı anın gerçeklerine uzak bir yaklaşımla Dorn'a yönelmiştir. Bir zamanların gözde doktoru olarak şimdide var olamayacağının bilincinde olan Dorn'dan karşılık bulamayan Polina, dördüncü perdeye gelindiğinde Medvedenko'yla evli olan kızı için Treplev'den güler yüz dilemektedir. Polina, Treplev'e "Kostya, arada bir güler yüz göster bir kadına, başka bir şey istemez senden. Kendimden bilirim...” derken 
aslında kendisinin kocasıyla yaşadığı mutsuz evliliğin bir tekrarını kızının yaşadığının farkında oluşunu imler. Ancak, Polina'nın Dorn'dan, güleryüzden fazlasını beklediği oyun boyunca altı çizilmiş bir durumdur. Öyle ki, Polina, oyunun birinci perdesinde Dorn'dan onu yaşadığı hayattan çekip çıkarmasını, hatta birlikte kaçmalarını önerir.

Dördüncü perdedeki "çiftliğe geliş” ana tekrar ekseniyle oyun kişilerinin diğer perdelerde olduğu gibi alt tekrar eksenlerine yöneldikleri görülür, gitmek ve gelmek temel tekrar ekseninin ateşleyici etkisiyle alt tekrar eksenlerinde hareket eden oyun kişilerinden yalnızca biri; Treplev bu tekrar çemberini kıracaktır.

Dördüncü perdeye gelindiğinde Sorin, hasta yatağındadır, durumunun kötüye gittiğinin farkında olmasına rağmen yaşama isteğinin altını çizer. Sorin'in son perdedeki yönelimi olan "yaşama isteği”" alt tekrar eksenine "Geçmiş", "Gelecek" ve "Sağllk" tekrarlarıyla ulaşılır.

Trigorin, oyun boyunca Arkadina ile birlikte "gelmek / gitmek" temel tekrar ekseni oluşturmuş; her perdede çiftliğe geliş gidişleriyle oyun kişilerinin belirli tekrarlara yönelmesini sağlamıştı. Üçüncü perdeyle dördüncü perde arasındaki iki yıllık zaman diliminde Trigorin, Nina ile bu kaçamak bir ilişkiyi yaşamış, hatta bir bebekleri olmuştur. Ancak, Trigorin Nina ile yaşadığı ilişki boyunca Arkadina ile bağlarını koparmamış, Nina'yla yaşadığı ilişkiyi tüketince Arkadina'ya tamamen geri dönmüştür. Dördüncü perde, Trigorin'in Nina ile yaşadığg ilişkinin hiçbir izini taşımadığının göstergeleriyle doludur. Şamrayev'e doldurtmasını istediği martıyı, dolayısıyla mahvettiği kızı ve öyküsünü hiç hatırlamaktadır. Buradan hareketle Trigorin'in Nina'ya yönelişinin altında yatan gerekçeler doğrulanmış olur: Gençliğini yazar olarak kendisini kabul ettirmeye uğraşmakla geçiren Trigorin için Nina geç bir gençlik hevesinden başka bir şey olmamıştır.

Trigorin, bugünde varolabilmek adına Arkadina ile ilişkisine de, yazarlık serüvenine de devam etmektedir. Araya giren Nina kaçamağına rağmen Arkadina ile ilişkisi sürmektedir. Diğer üç perdede görüldüğü gibi, yaşamak için sürekli yazıyor olmaktan bıkmış, kendini ve yazdıklarını onaylatmak zorunda olmaktan yorulmuştur. Ancak bugünde var olmak için başka çaresi olmadığı için bu döngünün devam edeceği açıktır. Bu göstergenin bir göstereni "Ben böyle bir yerde, böyle bir göl klyısında yaşasam elime kalem mi alırdım yazmak için? İçimdeki bu tutkuyu yener, balık tutmaktan başka bir şey yapmazdım." repliği ise bir diğer göstereni Trigorin'in yazabilmek için sürekli malzeme toplamak zorunda oluşunun vurgulandığı “ (...) Ha, bir de hani parkta oyununuzun sahnelendiği bir yer vardl, anımsadınız mı bilmem, orayı görmeliyim. Bir hikaye konusu olgunlaştı da kafamda... Ama olay yerini belleğimde tazelemem gerekiyor... " repliğidir. 
Birinci perdede Trigorin'in Arkadina ile çiftliğe gelmesi sakin çiftlik yaşamında beklenmedik bir harekete neden olmuş, oyun kişilerinin yönelimlerini belirlemişti. Dördüncü perdede ise, Trigorin ve Arkadina'nın çiftliğe gelişi, bu kez çok daha etkili bir durumun oluşmasını sağlayacaktır. Trigorin, şehirden gelirken yanında içinde hem kendisinin hem de Treplev'in birer öyküsünün yayınlandığı bir dergi getirecek, ancak Treplev, kendi öyküsünün ne annesi ne de Trigorin tarafindan okunmadığını anlayacaktır. Bununla birlikte Nina'nın çiftliğe gelişinin Trigorin'in de olduğu bir zamana denk düşmesi, Nina'nın tüm yaşadıklarına rağmen halen Trigorin'i sevdiğini söylemesi Treplev'in intiharına giden yolu açan anahtarlar olacaktır.

Trigorin'in, dördüncü perdede Treplev'e getirdiği dergi, söz konusu perdedeki en önemli anahtardır. Trigorin'in Treplev'den övgüyle söz etmesine, hayranlarının onu nasıl merakla izlediklerinden dem vurmasına rağmen dergideki öykünün annesi ve Trigorin tarafindan okunmadığını anlayan Treplev, yaşadığı mutsuz, umutsuz ve geleceksiz tekrar çemberini kıracak; intihar edecektir. Trigorin'in bu perdedeki yönelimi "sanat ile ilgi”, "başarı" ve "geçmiş” tekrarlarıyla oluşur.

Oyun boyunca sevgilisi Trigorin ile birlikte çiftliğe gidip gelişleriyle diğer oyun kişileri için ateşleyici güç oluşturan, yönelimlerin belirlenmesinde etkili olan Arkadina, dört perdede de "bugünde varolma savaşı" ile öne çıkar: Oyunun her perdesinde sahip olduğu konumu yitirmemek adına savaşım verir. Yaşını saklaması, kimseye para vermemesi, yenilikçi her türlü yaklaşımı itham etmesi hatta Treplev'e yeterli ilgiyi göstermemesi bu sebeptendir. Birinci perdede gelişi ile uyuyan çiftlik yaşamını uyandıran Arkadina, oğlu Treplev'in yenilikçi oyununu aşağılar, yeni biçim arayışlarını alaya alır, ikinci perdede aynı tutuma paralel olarak ne kadar genç göründüğünden, her yaşın rolünü oynayabileceğinden ve çiftlikte ne kadar sıkıldığından söz ederek devam ettirir bugünde varolma savaşını. Üçüncü perdede ise Arkadina'nın varolma savaşı, sevgilisi Trigorin'i Nina'ya kaptırmamak üzerine kurulur. Dördüncü perdeye gelindiğinde ise ağabeyi Sorin'in hastalığı üzerine geldiği çiftlikte abartılı bir biçimde son dönemde gördüğü ilgiyi anlatır. Söz konusu perdede Arkadina'nın Trigorin'in getirdiği dergideki öyküyü okumamış olması, Treplev için bir ateşleyici güç oluşturur. Treplev, annesinin ve Trigorin'in yazdıklarını okumayışını başarısız bir yazar olmasına bağlayacak ve Nina'nın gidişinin ardından kendisini vuracaktır.

Oyunun genç kuşağını temsil eden oyun kişilerinden biri olan Nina, Treplev'in sanat anlayışını, yeni biçim arayışlarını anlamadığını oyunun birinci perdesinden başlayarak dile getirir. Oyun boyunca Trigorin'in popüler eserlerine ve Arkadina'nın ününe olan hayranlığının altını çizer. Trigorin ve Arkadina'nın çiftliğe gelmelerinin ateşleyici gücüyle Nina'nın oyunun birinci perdesindeki yönelimi belirlenir: “Aktris olma isteği”. Üvey annesinin ve babasının baskısından kurtulmayı şehre 
gidip ünlü bir aktris olmaya denkleyen Nina, Trigorin'e ve Arkadina'ya olan hayranlığının da yardımıyla oyunun birinci ve ikinci perdelerinde şehre gidip ünlü bir aktris olma hayalleri kuracak, üçüncü perdenin sonunda şehre gidecek ancak ikinci sınıf bir oyuncu olmayı başarabilecektir. Dördüncü perdede Nina'nın iki yıllık zaman diliminde geçen öyküsü önce Treplev'in daha sonra da kendi ağzından duyulur. Üçüncü perdenin sonunda şehre giden Nina, şehirde beklediği başarıyı yakalayamamış, ünlü bir aktris olmak bir yana ancak kasabalar arasında mekik dokuyan bir oyuncu olabilmiştir. Şehirdeyken Trigorin ile yaşadığı ilişki, Trigorin'in umursamazlığının tersine Nina'yı derinden sarsmıştır. Gelinen noktada Nina'nın öyküsü ile Trigorin'in ikinci perdede yazmayı tasarladığ 1 öykü birleşmiş; Trigorin, "Küçük bir hikaye konusu. Çocukluğundan beri göl klyısında yaşayan bir genç klz var, sizin gibi biri; tıpkı bir martı gibi mutlu ve özgür. Günün birinde bir adam geliyor oraya, kızı görüyor ve yapacak bir işi olmadiğından yazık ediyor kıza, tıpkı bir martı gibi..." diyerek tasarısını yaptığı öyküyü yaşama geçirmiştir. Nina'nın “Bir martıyım ben” repliğini de bu bağlamda okumak gerekir.

Nina, Trigorin ile yaşadığı umutsuz aşk, kaybettiği çocuğu ve ancak ikinci sınıf bir oyuncu olmayı başarabilmesiyle "bugün"de mutsuzdur. Ne var ki, gelecek için de bir umut taşıması söz konusu değildir. Çiftlikten ayrıldığında aynı döngüyü yaşayacağı, bu tekrar çemberini kıracak gücü olmadığı açıkça görülmektedir. Sorin çiftliğine gelmesini onaylamayan anne ve babası yüzünden diğer üç perdede hep bir zaman sıkıntısı yaşayan Nina, kaçarcasına geldiği çiftlikten yine kaçarak ayrilır. Oyunun birinci perdesinde yakalanan bu durum oyunun sonunda yine tekrarlanacak, gizli gizli geldiği çiftlikten yine benzer bir biçimde kaçarcasına ayrılacaktır.

Oyunun tekrar çemberini kıracak tek oyun kişisi olan Treplev, köye de kente de ait olmayan bir oyun kişisidir, yenilikçi bir yazar olma yolunda kentte yaşaması gerekirken, ekonomik sıkıntılar nedeniyle üniversitenin üçüncü sınıfından ayrılmış, yine aynı nedenle dayısının yanında, çiftlikte yaşamak zorunda kalmıştır. Sahip olduğu entelektüel özelliklerle köye yabancı, annesinin soylu kimliğine uzaklığıyla şehre yabancıdır. Dördüncü perdeye gelindiğinde Trigorin'in getirdiği derginin içindeki öyküsünü ne annesinin ne de Trigorin'in okuduğunu anlayınca kendisini başarısız bir yazar olarak görür. Bu noktada birinci perdeden itibaren yazarlık serüveniyle koşut bir biçimde yaşadığ 1 Nina'ya olan aşkı da devreye girer. Öyle ki, birinci perdede Treplev'in yazdığı oyunun tek oyuncusu Nina'dır. Nina'nın ilgisizliğini yine yazma süreciyle koşut bir biçimde algıladığının göstergesinin göstereni ikinci perdede, "Oyunumun öyle aptalca başarısızlığa uğradığı akşam başladı bu. Kadınlar başarısızlığı bağışlamazlar. Hepsini yaktım onun, hepsini, tek bir kırpıntı kalmamacasına. Ne kadar mutsuz olduğumu bilseniz!” repliği ise, üçüncü perdedeki göstereni de “Ah, bilseydin! Her şeyimi yitirdim! Beni sevmiyor, yazamaz oldum artık, tüm umutlarım yok oldu..." repliğidir. Dördüncü perdeye gelindiğinde ise kendisini, eleştirdiği Trigorin'in popüler öykülerini dahi yazamayacak kadar 
başarısız bir yazar olarak düşündüğü sırada çiftliğe gelen ve hala her şeye rağmen Trigorin'i sevdiğini söyleyen Nina'nın gidişinin ardından vurur. Bir başka deyişle hem yazma becerisini hem de Nina'yı yitirdiğini düşündüğü noktada intihar eder.

Bu bağlamda, oyunun tekrar çemberini kıran tek oyun kişisi Treplev olur. Treplev dışındaki tüm oyun kişileri bugünde var olma savaşı ile geleceksizlik arasında sıkışıp kalırlar. Dördüncü perdenin temel tekrar ekseni “Trigorin ve Arkadina'nın Sorin'in hastalığı yüzünden çiftliğe gelişi”dir. Arkadina ve Trigorin iki yıl süren bir aranın ardından yeniden geldikleri çiftlikte oyun kişilerinin yaşamlarını yine hareketlendirirler. Sorin hastalı̆̆ının ciddiyetine rağmen yaşama ısrarını sürdürürken, Treplev, Trigorin'in getirdiği dergideki öyküsünün annesi ve sevgilisi tarafından okunmadığını anlayınca başarısız bir yazar olduğunu düşünecek, Nina'nın gelişi Trigorin'in de çiftlikte bulunduğu bir zaman denk düşecek ve Nina Trigorin'i hala sevdiğini söyleyince Treplev hem Nina'ya olan aşkının hem de yazarlık serüveninin son bulduğunu düşünerek kendisini vuracaktır.

Topraklarda kölelerin çalıştırıldığı yıllardan kalan varlıklarını toprak köleliğinin kaldırılmasıyla yitirmeye başlayan soylu kökenli aydın kesimin üyeleri yaşadıkları köklü değişime direnirlerken kendilerini sürekli tekrar eden bir geleceksizlik çemberinin içinde bulurlar. Değişim dönemecine takılıp kalan oyun kişileri kendilerini söz konusu tekrar çemberine tutsak eden süreci çözümlemeye yönelik bir güce sahip değildirler. Toprak kölelerinin çiftliklerde çalıştırıldığı zengin yıllarında, topraktan elde ettikleri gelirle şehirlerde rahatça yaşayabilmişler, iyi okullarda eğitim görebilmişlerdir. Ancak, değişen koşullar çiftliklerin şehir yaşamının lüksünü beslemesini imkansız kılmıştır. Bu noktada eskiden yaz tatilleri için uğradıkları çiftliklerde bugün yaşamak zorunda kalan oyun kişileri karşımıza çıkar. Sözü edilen oyun kişilerinin hiçbiri için bir gelecek tarif edilmez: Yaşlı kuşağın temsilcilerinden olan Sorin kadar genç Maşa'da geleceksizdir; Arkadina ve Trigorin bugünde varolma savaşını gelecekte yerleri olmadığını bildiklerinden verirler; Nina "şimdi"de de mutsuzdur gelecekte de mutsuz olacağı açıktır. Bu noktada söz konusu tekrar çemberini kıran tek oyun kişisinin Treplev olduğu saptanmış olur. Çünkü, şehirde yaşayacak parası olmadığından çiftlikte tutsak Sorin, içinde yaşadığı çemberi kırmak için hiçbir eylemde bulunamaz, en fazla "bugünü" biraz daha fazla yaşayabilmek için doktordan ilaç ister. Birinci perdede yaşama ısrarı ne denli fazlaysa dördüncü perdede de ağırlaşan sağlık durumuna rağmen aynı biçimde 1srarlıdır. Arkadina ve Trigorin'in bugünde varolma savaşlarında da benzer bir tekrar görülür. Oyunun başından itibaren aralarında bir "aşk" ilişkisinden çok bir tür "iş anlaşması" olduğu, varolan statülerini kaybetmemek adına birbirlerinden nasıl faydalandıkları görülür. Oyunun sonuna gelindiğinde de aynı savaşım içinde birlikteliklerini sürdürmekte oldukları, araya giren Nina - Trigorin ilişkisinin iş anlaşmalarına zarar vermediği anlaşılır. Arkadina, statüsünü koruyabilmek için yeni biçim arayışlarını küçümsemeye, hiçbir gerekçeye dayandırmadan yenilikçi denemeleri yozlukla suçlamaya devam ederken, Trigorin 
oyunun başında olduğu gibi bıkmış olsa da yazmak zorunda olduğu eserler için malzeme toplamayı tekrarlar. Birinci perdede Nina - Treplev birlikteliğine özenen Medvedenko, dördüncü perdede Maşa ile evlenmiş, bir de bebeği olmuştur. Ne var ki, Maşa kocasıyla evinde değil, Treplev'i rahatça görebildiği Sorin çiftliğinde kalmayı yeğler. Oyunun başında sevdiği kızı görebilmek için altı verst yolu yayan gelen Medvedenko, oyunun sonunda bu kez karısı olmuş Maşa'yı alıp evine götürebilmek için aynı yolu yürümektedir. Üçüncü perdenin başında Medvedenko'yla evlenme kararı alan Maşa, Treplev'e olan sevgisini yüreğinden sökeceğini söyler, ancak dördüncü perdeye gelindiğinde Treplev'e olan aşkından doğan duygusal açmazdan sıyrılamamış olduğu görülür. Şamrayev'in geçmişi bugünde yaşatmaya çalışmasının tekrarına, birinci perde de dördüncü perde de bugünde varlığını sürdürme savaşı veren Arkadina'ya oyunculuğu bırakmış eski ünlü oyuncular hakkında sorular sorması örnek gösterilebilir. Aynı tutum birinci perdeden başlayarak Polina'da da gözlenir. Kocasının davranışlarından bıkmış, aşık olduğu Doktor Dorn'un onu Şamrayev'den kurtaracağına inanmıştır. Dorn ise, tıpkı, Polina, Şamrayev ve Sorin gibi var oluşunu geçmişle belirlemiştir. Bir zamanların gözde doktoru olarak şimdide var olamayacağının bilincindedir. Polina, tıpkı oyunun şehirde yaşamayan görece yaşlı kuşağının temsilcileri kocası Şamrayev ve aşığı Dorn gibi, geçmişi bugünde yaşatmakta kararlı, geçmişin geçmişte kaldığ gerçeğini kabul etmemekte 1srarlıdır. Üvey annesinin ve babasının baskısından kurtulmayı şehre gidip ünlü bir aktris olmaya denkleyen Nina ise, Trigorin'e ve Arkadina'ya olan hayranlığının da etkisiyle oyunun birinci ve ikinci perdelerinde şehre gidip ünlü bir aktris olma hayalleri kuracak, üçüncü perdenin sonunda şehre gidecek ancak ikinci sınıf bir oyuncu olmayı başarabilecek, kendisini geleceksizlik çemberinin içinde bulacaktır. Buradan hareketle Treplev'in, oyunun üzerine oturduğu tekrar çemberini kıran tek oyun kişisi olduğu saptanır. Treplev, iyi bir yazar olamayacağını ve Nina’yı kaybettiğini anladığında kendisini vurur. Treplev'in intiharı yaşanılan tekrar çemberini kıran tek eylem olarak oyunun finalini oluşturur. 


\section{KAYNAKÇA}

Çehov, Anton. Bütün Oyunları II. Çev.: Ataol Behramoğlu. İstanbul: Türkiye İş Bankası Kültür Yayınları, 2002.

Saussure de Ferdinand. Genel Dilbilim Dersleri. Çev.: Berke Vardar. İstanbul: Multilingual Yayınları, 1998.

Şener, Sevda. Yaşamın Kırılma Noktasında Dram Sanatı.İstanbul: Yapı Kredi Yayınları, 1997.

Şener, Sevda. “Anton Çehov'un Oyunlarında Uzam ve Zaman,” Çăgdaș Eleștiri, Ekim, 1983.

Yüksel, Ayşegül. Yapısalcılık ve Bir Uygulama.Ankara: Gündoğan Yayınları, 1995. 